\title{
On a Field Trip with Bourdieu
}

\author{
Adler-Nissen, Rebecca
}

Published in:

International Political Sociology

DOI:

10.1111/j.1749-5687.2011.00137_1.x

Publication date:

2011

Document license:

Other

Citation for published version (APA):

Adler-Nissen, R. (2011). On a Field Trip with Bourdieu. International Political Sociology, 5(3), 327-330.

https://doi.org/10.1111/j.1749-5687.2011.00137_1.x 


\title{
Inter- and Transnational Field(s) of Power
}

\section{On a Field Trip with Bourdieu}

\author{
Rebecca Adler-Nissen \\ University of Copenhagen
}

How can Bourdieu help us grasp international politics today? How can the concept of "field," originally coined for analyzing relations within states, provide an understanding of emerging patterns of transnational governance? I argue that Bourdieu provides us with sophisticated analytical tools for exploring the strength and limits of state authority - also beyond the national territory. Moreover, I claim that sovereign state interaction-diplomacy-has developed into a metafield. If we are to understand emerging challenges to state authority, from private companies to international organizations and global media, we need to study everyday activities, which both reproduce and challenge the sovereign state system as a meaningful reality. I illustrate this idea of competing articulations of political authority by focusing on the EU's new diplomatic service, which challenges the very idea of national diplomatic representation.

\section{The Field of the State}

A Bourdieusian reading of "the international" turns traditional IR theory upside down. When neorealists claim that the international system is anarchical, Bourdieu insists that it is hierarchical. When the English School claims that "pariah states and failed states" can be seen as being somehow outside international society relegated to a more abstract international system "with less dense interaction" (Dunne 2010:148), a Bourdieu-inspired approach argues that processes of exclusion are intrinsic to international society. Muammar Gaddafi's Libya, for instance, only becomes a "pariah state" through interaction with the rest of the world.

While this might sound like a constructivist argument about the social character of international politics, Bourdieu is not an IR constructivist. Anarchy is not what states make of it because the international is already structured. States come with a history. The marginalization of some states, groups, or individuals can be explained by the changing patterns of cultural and symbolic forms of domination and the competition for power and prestige.

To Bourdieu, the particularity of the state as an organization, born by and geared for power concentration, is not material. The specificity of the state is not the accumulation of legitimate physical violence (as Weber would have it), but the monopolization of legitimate symbolic violence. The state is first and foremost "a central bank for symbolic credit," which makes social division, 
privileges, and domination universally valid within a given territory and for a given population (Bourdieu 1989). The state is special because it does not compete for the definitions of, for example, legal and educational status, because it already has pre-eminence over these areas, and it is a metafield (Chopra 2003:429). This means that the influence of the state as a reference point in social life works not in one field only, but across all fields.

If the field of power - the field of the state-is in itself a field of struggle, it also becomes clear that it is misleading to see the state as a homogenous or unitary actor. The state itself is not a singular entity and in a very real sense is divided among and within its various agencies and elected bodies. Moreover, as Chopra notes, the state is incorporated in its citizens. The state, in this manner, shapes structures of perception and cognition across the society that the state governs. This is what Bourdieu means by the phrase "minds of state" (Bourdieu 1994:13) suggesting that the state exists as much an entity "outside" of its citizens as it exists "of" the citizens (Chopra 2003:430).

Consequently, national representatives negotiate with different "minds of state." When German foreign minister Guido Westerwelle on March 17, 2011, declared that Germany remained strongly opposed to NATO-led air strikes against Muammar Gaddafi's forces or any other military intervention in Libya, he talked from a specific position in the German political landscape. Similarly, when US President Barack Obama, UK Prime Minister David Cameron, and French President Nicolas Sarkozy agreed on a military operation against Libyan forces, they built on different symbolic power and national bureaucratic structures.

Critics might argue that this does not bring us much further than the foreign policy analysis of Graham Allison. Recognizing the importance of bureaucratic structures and power struggles within the state does not tell us how international relations work. Indeed, in the meetings between states, one single state cannot (a priori at least) structure the meaning of social interaction.

\section{The Metafield of Diplomacy}

The development of the military operation in Libya begs the question of whether there are transnational fields that structure international relations. Or put in Bourdieusian terms: Is there a universal currency of capital that travels across international fields? Or is the international realm too heterogeneous to produce any kind of shared understanding of what counts as a power resource?

When national representatives meet, be it in multilateral and bilateral contexts, the state is no longer the structuring and dominant field of power as is the case in Bourdieu's work. Rather, it is a distinct field where they meet that structures their positions (see also Pouliot 2010). Particular struggles take place when national representatives meet in, say, New York, Brussels, or Beijing, a struggle that is relatively autonomous from struggles within the states.

Diplomacy, the management of sovereign state relations, I argue, has developed into a metafield. Consequently, diplomatic interaction helps structure what goes on in fields of e.g. global finance, war, and international law. While these fields are developing relatively autonomously and may end up constraining states, they usually begin and end with diplomatic negotiations. From the drafting of international human right treaties to the formal ending of hostility at peace negotiations, state-based diplomacy still frames what is possible. We can also examine how distinct transnational practices have developed in partial isolation from the diplomatic field, that is, transnational criminal networks such as the Italian-American mafia that function symbolically in opposition to the state. Yet we may also observe how private military companies such as XE Services are co-opted into the 
diplomatic field, as when protecting civil servants in Afghanistan. The metafield of diplomacy, in other words, is changing as global and transnational actors develop new networks of knowledge and authority (Constantinou and Der Derian 2010).

Diplomacy did not become a metafield overnight. The sovereign state system is anchored in histories of prejudices, colonization, and global economic flows (Anghie 2005). Today, diplomacy often reproduces inequality without any apparent violence, that is, through symbolic violence. Existing IR theories are implicated in this symbolic violence as they explicitly or implicitly help legitimize the sovereign state system, and hence a specific form of political organization, making concepts of "world society" or "empire" inferior to the sovereign state (see Bigo and Walker 2007).

Why are some states seen as more powerful than others? Oft-mentioned sources of power in IR theory are military strength, economic size, geopolitical position as well as negotiation expertise and cultural attractiveness. All of these proposed power sources may be exchanged into diplomatic capital. It requires that they are accepted as valid in the field, that is, the power that comes with a social position and affords prestige and leads to others paying attention to you. The execution of power demands legitimacy; in order to understand how this is achieved, one must examine the underling institutions that legitimize the power and contribute to making a historically arbitrary social order seem inevitable and natural.

\section{Emerging Transnational Powers}

Critics might object that my reading of diplomacy as a metafield is too conventional. If diplomacy constitutes a metafield, then basically we are left with the state. Doesn't this make us blind us to dynamics that transcend the nation-state? I would say no. States are not the only actors in diplomacy. The question is how state sovereignty plays out in relation to other articulations of authority. Today, states need to justify themselves in global media such as CNN and Al Jazeera, while NGOs such as Amnesty International and international authorities such as the European Court of Human Rights effectively challenge the arguments made by governments. What makes such challenges successful?

For Amnesty International, prospective states such as Kosovo or supranational organizations to establish themselves as legitimate authorities, they need to produce particular perceptions and categories that have to count as valid and legitimate. It is possible for NGOs and international organizations to become so successful that they transform the dynamics of the sovereign state system. One example is the European Union. In 2009, the EU's Treaty of Lisbon entered into force and a fully integrated European foreign service was created. This first genuine transnational diplomatic body, the European External Action Service (EEAS), comprises staff of 3,000-5,000 diplomats. They come from the European Commission, the Council secretariat as well as staff seconded from the diplomatic service of member states. The EEAS challenges the metacapital of the state, that is, ability to uphold its monopoly of symbolic violence (Adler-Nissen 2011). As Jan Gaspers writes, "this Service not only has the potential largely to determine the EU foreign policy agenda and shape the Union's external appearance, but it will also increasingly pose a threat to member states' national diplomacy" (Gaspers 2010:20).

The reference point for the EU's diplomatic service is that of a national foreign service. This is not innocent. According to the High Representative of the Union for Foreign Affairs and Security Policy, Catherine Ashton, one of the biggest challenges is how the EU delegations can become just as recognizable and recognized as a national embassy: 
When you go into an embassy of a member state anywhere in the world, you know which country you are in. How will it be that when you go in to look up the External Action Service somewhere in the world, you'll know that you are with Europe? It's that feeling of "this is what we do and this is what we do well." (Ashton, quoted in O'Connor 2010:14)

Being recognized as a "true" diplomacy, having the symbolic power of a statelike construction, is crucial to the success of the EEAS. The European Union is not likely to become a recognized as a powerful foreign policy power by China, for example, until it gains the upper hand vis-à-vis its member states in excising symbolic power.

The European Union, however, is not likely to replace national diplomacy. Instead, we see a hybridization. On the one hand, national ambassadors start recognizing the diplomatic capital of an EU diplomat. On the other hand, the EEAS begins acknowledging the capital and resources of the 27 diplomatic "state nobilities." Capital from national diplomatic services must be exchanged into power in Brussels: that is, a clear exchange rate must be established, thereby guaranteeing both national diplomatic elites and Commission officials that they will not lose market value, but keep their distinctions and privileges when they participate in the European diplomatic experiment. It may well be that European and national diplomacy becomes so intertwined as practices that we should talk of a merged "European-national diplomatic field."

While the state currently enjoys ontological priority, there are emerging and rival ways of organizing political life. Ashley is therefore only partly right when he claims that sovereignty "[i]s what one must do in order internationally to be" (Ashley 1989:257). If the struggle for dominant positions within the diplomatic field changes, other claims to authority may challenge the symbolic power of the state and transform the European diplomatic system. Bourdieu's field theory can help understand how.

\section{References}

Adler-Nissen, Rebecca. (2011) “EU’s Diplomatic Service: State Nobility, Supranational Bureaucracy and Symbolic Power" edited by Niilo Kauppi and Mikael Rask Madsen. Global Power Elites. London: Routledge, forthcoming.

Anghie, Anthony. (2005) Imperialism, Sovereignty and the Making of International Law. Cambridge: Cambridge University Press.

Ashley, Richard K. (1989) Living on Border Lines: Man, Poststructuralism, and War. In International/Intertextual Relations. Postmodern Readings of World Politics, edited by James Der Derian, and Michael Shapiro. New York: Lexington Books.

Ashton, Catherine. (2010) Proposal for the European External Action Service-Speech by EU HR Ashton. Brussels: European Commission.

Bigo, Didier, And R. B. J. Walker. (2007) Political Sociology and the Problem of the International. Millennium 35 (3): 725-739.

Bourdieu, Pierre. (1989) La Noblesse d'État. Grandes écoles et esprit de corps. Paris: Les Editions de Minuit.

Bourdieu, Pierre. (1994) Un acte désintéressé est-il possible? In Raisons pratiques. Sur la théorie de la raison, edited by Pierre Bourdieu. Paris: Le Seuil.

Chopra, Rohit. (2003) Neoliberalism As Doxa: Bourdieu's Theory of the State and the Contemporary Indian Discourse on Globalization and Liberalization. Cultural Studies 17 (3/4): 419-444.

Constantinou, Costas M., and James Der Derian. (2010) Introduction. In Sustainable Diplomacies, edited by Costas M. Constantinou, and James Der Derian. New York: Palgrave Macmillan.

Dunne, Tıм. (2010) The English School. In International Relations Theory. Discipline and Diversity, edited by T. Dunne, M. Kurki, and S. Smith. Oxford: Oxford University Press.

Gaspers, Jan. (2010) Putting Europe First. The World Today 1 (12): 20-22.

Pouliot, Vincent. (2010) International Security in Practice: The Politics of NATO-Russia Diplomacy. Cambridge: Cambridge University Press. 